\title{
EFEKTIFITAS KELAS CALON NENEK SEBAGAI PENDUKUNG ASI TERHADAP PELAKSANAAN ASI EKSKLUSIF HARI KE 1-3 DI DESA PANDEAN
}

\author{
Wahida Yuliana $^{1)}$, Bawon Nulhakim ${ }^{2)}$ \\ AKBID Hafshawaty Zainul Hasan Genggong Probolinggo \\ email: wahidayuliana44@gmail.com
}

\begin{abstract}
ABSTRAK
Dukungan masyarakat, baik secara perorangan, kelompok atau organisasi berupa kontribusi dalam program terkait pemberian ASI Eksklusif sangat berpengaruh terhadap praktek pemberian ASI eksklusif. Cakupan pemberian ASI eksklusif pada bayi umur 0-6 bulan tahun 2015 di JawaTimur 74,1 \% dan tahun 2016 menurun menjadi 31,3\%. Penelitian ini bertujuan untuk mengetahui penerapan Kelas calon nenek sebagai pendukung ASI terhadap pelaksanaan ASI Eksklusif. Penelitian ini menggunakan desain penelitian quasy experimental. Populasinya adalah seluruh ibu hamil trimester III di Desa Pandean yang berjumlah 30 orang. Teknik sampling yang digunakan adalah simple random sampling. Analisis yang digunakan adalah uji statistik chi-square tingkat kemaknaan 95\% (alpha 0,05) dengan menggunakan STATA 12. Hasil penelitian dari 30 responden, 11 responden (36,6\%) yang diberi kelas calon nenek melaksanakan pemberian ASI eksklusif hari ke 1-3 sedangkan 10 responden (33,3\%) yang tidak diberi kelas calon nenek tidak dapat melaksanakan pemberian ASI eksklusif. Kesimpulan penelitian ini adalah kelas calon nenek efektif dalam keberhasilan pelaksanaan ASI Eksklusif pada hari 1-3.
\end{abstract}

Kata kunci: kelas calon nenek, pendukung ASI, ASI eksklusif

\section{ABSTRACT}

The Community support, individual, group or organization in the form of contributions in programs related to exclusive breastfeeding is very influential on exclusive breastfeeding practices. The coverage of exclusive breastfeeding in infants aged 0-6 months 2015 in East Java was $74.1 \%$ and 2016 decreased to 31.3\%. This study aimed to determine the application of prospective grandmother classes as breastfeeding supporters of the implementation of Exclusive ASI. This research used experimental quasy research design. The population is all third trimester pregnant women in pandean village which amounts to 30 people. The sampling technique used is simple random sampling. The analysis used is chi-square statistical test of significance level 95\% (alpha 0,05) using STATA 12. The results of the study of 30 respondents, $36.6 \%$ of respondents (36.6\%) who were given grandmother grandmother class performed exclusive breastfeeding day 1-3 whereas 10 respondents (33.3\%) who were not given grandmother candidate class can not perform exclusive breastfeeding. The conclusion of this study is that grandmother class is effective in the successful implementation of Exclusive Breast milk on 1-3 days.

Keywords: grandmother's class, breastfeeding supporter, exclusive breastfeeding

\section{PENDAHULUAN}

Dukungan masyarakat, baik secara perorangan, kelompok atau organisasi berupa kontribusi dalam program terkait pemberian ASI Eksklusif sangat berpengaruh terhadap praktek pemberian ASI eksklusif. Peran keluarga sangat penting terutama motivasi, persepsi, 
emosi dan sikap ibu dalam menyusui bayinya (Susilo,dkk., 2012).

Masalah dalam pemberian ASI di Indonesia berdasarkan hasil analisis Riskesdas 2013 antara lain presentasi bayi yang menyusu eksklusif enam bulan sebesar 15,3\%, persentase inisiasi menyusu dini kurang dari satu jam setelah lahir sebesar 29,3\%, sebagian besar bayi mulai disusui pada kisaran waktu 1-6 jam setelah lahir, persentase proses menyusui bayi setelah 48 jam sebesar 48 jam sebesar 11,1 \% (Astuti, dkk., 2015). Cakupan pemberian ASI eksklusif pada bayi umur 0-6 bulan tahun 2015 di Jawa Timur 74,1\% dan tahun 2016 menurun menjadi 31,3 \% (Direktorat Gizi Masyarakat, Direktorat Jendral Kesehatan Masyarakat \& Kementerian Kesehatan RI, 2016).

Penelitian Widayati dkk. (2015), tentang pelatihan dan implementasi konselor peer-support berbasis masyarakat pada kelompok pendukung ASI eksklusif dilakukan dengan metode pemecahan masalah, konselor melakukan kunjungan rumah dan melakukan monitoring tindak lanjut terhadap permasalahan. Penelitian ini menjadi upaya dalam meningkatkan cakupan jumlah bayi yang diberikan ASI. Penelitian lainnya tentang dukungan keluarga terhadap ASI eksklusif oleh Ramdani \& Hadi (2010) menyebutkan $55,4 \%$ ibu memberikan ASI eksklusif dan $57 \%$ ibu mendapatkan dukungan dari keluarga.

Berdasarkan hasil studi pendahuluan di Desa Pandean Kecamatan Paiton pada tanggal 20 Agustus 2017 saat kegiatan pelaksanaan praktik asuhan masa nifas oleh mahasiswa semester IV melalui wawancara pada $10 \mathrm{ibu}$ nifas didapatkan data bahwa ibu yang memberikan MPASI berupa susu formula pada hari ke 2 dan 3 berjumlah 6 orang dari $10 \mathrm{ibu}$ nifas. Ibu merasa ASI tidak lancar dan ibu mertua tidak mendukung memberikan ASI eksklusif. Ibu mertua menyarankan memberikan bantuan makanan selain ASI saat ASI dianggap kurang dan melanjutkan pemberian ASI jika sudah lancar. Ibu nifas tidak bisa menolak anjuran dari ibu mertua meskipun sudah memahami penjelasan mengenai ASI eksklusif dari bidan selama pemeriksaan kehamilan. Ibu mertua merasa lebih berpengalaman dalam mengasuh bayi terutama dalam pemberian nutrisi.

Peran ASI sangat penting bahkan berpengaruh terhadap risiko kematian. Pemberian ASI menyelamatkan 1,5 juta bayi pertahun dari kesakitan dan kematian pada bayi, banyak pihak mengakui bahwa mengatasi kematian pada bayi dari segi medis tidak sulit dibanding mengatasi masalah non medis seperti aspek sosial dan budaya (Pranata, dkk., 2011). Pengalaman orang tua serta kebiasaan yang dilakukan di lingkungan sekitar dapat berpengaruh terhadap praktek pemberian ASI eksklusif. Ibu mertua yang merupakan bagian dari kelurga ibu menyusui dapat memberikan pengaruh yang besar bagi ibu menyusui.

Pada penelitian ini para mertua ataupun orangtua perempuan dari ibu nifas dapat menjadi kelompok pendukung ASI karena posisinya sebagai orangtua dapat sangat mempengaruhi terhadap terlaksananya ASI Eksklusif. Berdasarkan evaluasi kelas antenatal dengan ibu hamil dikelompokkan dengan sesama ibu hamil merasa puas dan menarik dalam mengikuti kegiatan ibu hamil (Hodgson et all. 2017). Kelompok pendukung ASI yang terdiri dari calon nenek dapat dijadikan kelas calon nenek sebagai pendukung ASI. Kelas calon nenek ini diharapkan dapat meningkatkan pemberian ASI Eksklusif.

Tujuan Penelitian ini adalah untuk menganalisis Efektifitas kelas calon nenek sebagai pendukung ASI terhadap pelaksanaan ASI eksklusif hari 1-3 di Desa Pandean.

\section{METODE PENELITIAN}

Rancangan penelitian yang digunakan adalah Quasi experiment yang berbentuk static group comparation Terdapat dua kelompok yang dipilih sebagai obyek penelitian dengan kelompok pertama mendapat perlakuan dan kelompok kedua tidak mendapat perlakuan. Penelitian dilakukan pada bulan Maret-Mei 2018.Teknik sampling 
yang dipilih Simple random sampling dengan jumlah 30 responden. Responden adalah ibu hamil trimester III. Instrumen penelitian yang digunakan adalah SAP kegiatan kelas calon nenek dan lembar Penilaian memberikan ASI Eksklusif. Pengamatan dilakukan mulai nifas hari 1 sampai dengan hari ke 3 . Analisis yang digunakan adalah uji statistik chi-square tingkat kemaknaan 95\% (alpha 0,05).

\section{HASIL DAN PEMBAHASAN}

Subyek penelitian berjumlah $30 \mathrm{ibu}$ hamil trimester III di Bidan Lilik dan Bidan Maya Desa Pandean Kabupaten Probolinggo. Berikut tabel distribusi karakteristik subyek penelitian di BPM lilik dan BPM Maya di Desa Pandean pada bulan Maret-Mei 2018:

Tabel 1. Distribusi Karakteristik Subyek Penelitian di Desa Pandean Kabupaten Probolinggo Maret-Mei $2018(\mathrm{n}=30)$

\begin{tabular}{llcc}
\hline \multicolumn{1}{c}{ Karakteristik } & \multicolumn{1}{c}{ Kategori } & N & \% \\
\hline Usia & Produktif $(20-35$ tahun $)$ & 21 & 70 \\
\multirow{3}{*}{ Pendidikan } & Tidak Produktif $(<20$ tahun;>35 tahun $)$ & 9 & 30 \\
\multirow{3}{*}{ Paritas } & Tinggi & 21 & 70 \\
& Rendah & 9 & 30 \\
& Multipara & 17 & 56.6 \\
& Primipara & 13 & 43.3 \\
\hline
\end{tabular}

Analisis univariabel bertujuan untuk mendeskripsikan karakteristik dari subjek penelitian. Hasil analisis univariabel yang dilihat dari beberapa variabel didapatkan gambaran karakteristik subyek penelitian kelompok kontrol, dan kelompok yang mendapatkan kelas calon nenek dalam tabel 1. Analisis univariabel ini untuk mengetahui varians data pada dua kelompok sama atau berbeda.

Tabel 2. Efektifitas Kelas Calon Nenek sebagai Pendukung ASI terhadap Pelaksanaan ASI Eksklusif hari ke 1-3 Desa Pandean Kabupaten Probolinggo Maret-Mei $2018(\mathrm{n}=30)$

\begin{tabular}{|c|c|c|c|c|c|c|c|}
\hline \multicolumn{7}{|c|}{ Jenis Nutrisi } & \multirow{3}{*}{$\mathbf{P}$} \\
\hline \multirow{2}{*}{ Kelas Calon Nenek } & \multicolumn{2}{|c|}{ ASI Eksklusif } & \multicolumn{2}{|c|}{ MP ASI } & \multicolumn{2}{|c|}{ Total } & \\
\hline & $\mathbf{f}$ & $\%$ & $\mathbf{f}$ & $\%$ & f & $\%$ & \\
\hline Tidak diberi & 5 & 16.67 & 10 & 33.33 & 15 & 50 & \\
\hline Diberi & 11 & 36.66 & 4 & 13.33 & 15 & 50 & 0.028 \\
\hline Total & 16 & 53.33 & 14 & 46.66 & 30 & 100 & \\
\hline
\end{tabular}

Berdasarkan hasil penelitian mengenai efektifitas kelas calon nenek sebagai pendukug ASI terhadap pelaksanaan ASI eksklusif hari ke 1-3 didapatkan data bahwa sebanyak 11 orang (50\%) yang diberi Kelas calon Nenek melaksanakan ASI Eksklusif. Kelas calon Nenek berpengaruh terhadap keberhasilan pemberian ASI Eksklusif pada hari ke 1-3 dengan hasil pvalue $<0,05$.

ASI Eksklusif atau tepatnya pemberian ASI secara Eksklusif adalah bayi hanya diberikan ASI saja tanpa tambahan cairan lain seperti susu formula, jeruk, madu, air teh, air putih dan tanpa pemberian tambahan makanan padat seperti pisang, papaya, bubuk susu, biscuit, bubur nasi dan tim (Astuti, dkk., 2015).

WHO merekomendasikan ASI Eksklusif selama enam bulan pertama kehidupan. Pada usia enam bulan, bayi diperkenalkan makanan padat seperti buah-buahan dan sayuran yang dihaluskan untuk melengkapi ASI sampai anak berusia 2 tahun. Menyusui harus 
dimulai segera dalam satu jam setelah melahirkan. Pemberian ASI sesering yang diinginkan oleh bayi siang dan malam serta hindari botol atau dot (Astuti, dkk. 2015).

Faktor keberhasilan pemberian ASI eksklusif harus didukung dengan produksi ASI yang lancar. Permasalahan yang terjadi adalah ASI tidak keluar sehingga ibu dan keluarga memberikan makanan prelakteal. Pemberian makanan prelakteral yang paling banyak diberikan pada permasalahan ASI tidak lancar pada hari ke 1-3 sehingga tidak tercapainya ASI Eksklusif. Faktor-faktor yang mempengaruhi produksi ASI adalah paritas, IMT dan frekuensi menyusui. Selain itu, hasil penelitian menyebutkan bahwa terdapat perubahan peningkatan produksi air susu ibu yaitu kelompok intervensi pijat punggung menggunakan minyak essensial lavender (Yuliana, 2016).

Kelompok pendukung ASI Eksklusif merupakan wadah partisipasi berbasis masyarakat dalam mengembangkan pembangunan kesehatan di tingkat desa. Kelompok pendukung ASI Eksklusif bertujuan untuk meningkatkan kesadaran, kemauan dan kemampuan untuk memberikan ASI Eksklusif pada bayinya. Kelompok ini memberikan pengalaman, keterampilan dan peningkatan motivasi ibu menyusui (Widayati, 2015).

Peran keluarga terhadap pemberian ASI Eksklusif sangat penting, terutama terhadap motivasi, persepsi, emosi, dan sikap ibu dalam menyusui bayinya. Pemerintah melakukan terobosan yang bersifat nasional untuk menggerakkan seluruh anggota masyarakat Indonesia terutama ibu-ibu dengan motivasi keluarga dalam memberikan ASI. Kegiatan kawal ASI mempunyai andil yang cukup besar dalam peningkatan cakupan ASI eksklusif (Susilo, dkk., 2012).

Masyarakat pada umumnya menyadari pentingnya pemberian nutrisi berupa ASI eksklusif. Pembekalan pengetahuan ibu menyusui sudah diberikan sejak kehamilan oleh bidan. Kendala yang sering terjadi saat hari pertama sampai hari ketiga masa nifas, seperti ASI tidak lancar, bayi sering sering menangis dan dianggap belum cukup hanya diberikan ASI saja. Maka perlu adanya pihak keluarga yang dapat memberikan solusi permasalahan untuk tetap memberikan ASI Eksklusif. Kegiatan kelas calon nenek merupakan kegiatan pembekalan calon nenek dalam memberikan dukungan ASI Eksklusif, sehingga para nenek memiliki peranan dan berdaya guna dalam memberikan solusi yang tepat.

Kegiatan kelas calon nenek ini merupakan kegiatan pemberdayaan serta secara komprehensif mendukung pencapaian ASI Eksklusif sesuai target nasional. Dukungan yang selama ini diberikan oleh calon nenek dapat dipantau oleh bidan dan meringankan tugas bidan dalam melaksanakan program pemerintah kaitannya dengan ASI Eksklusif.

\section{KESIMPULAN DAN SARAN}

\section{Kesimpulan}

Hasil penelitian dari 30 responden, 11 responden $(36,6 \%)$ yang diberi kelas calon nenek melaksanakan pemberian ASI eksklusif hari ke 1-3 sedangkan 10 responden $(33,3 \%)$ yang tidak diberi kelas calon nenek tidak dapat melaksanakan pemberian ASI eksklusif. Hasil uji statistic adalah pvalue $<0,05$. Kesimpulan penelitian ini adalah kelas calon nenek efektif dalam keberhasilan pelaksanaan ASI Eksklusif pada hari 1-3.

\section{Saran}

Penelitian ini mampu memberikan masukan profesi dalam mengembangkan perencanaan kebidanan yang akan dilakukan dalam mengetahui efektifitas kelas calon nenek sebagai pendukung ASI terhadap pelaksanaan ASI Eksklusif hari ke 1-3. Bidan dapat melakukan pemberdayaan masyarakat dengan membuka kelas calon nenek untuk memberikan dukungan kepada ibu menyusui ketika hari ke 1-3 yang paling banyak mengalami kendala saat menyusui. Kegiatan ini dapat menjadi upaya bidan meningkatkan cakupan ASI Eksklusif sesuai target nasional. 


\section{REFERENSI}

Astuti,S.,Judistiani, R., Rahmiati, L, \& Susanti, A. (2015). Asuhan Kebidanan Nifas dan menyusui. Jakarta:Erlangga

Direktorat Gizi Masyarakat, Direktorat Jendral Kesehatan Masyarakat \& Kementrian Kesehatan RI. (2016). Buku Saku pemantauan Status gizi dan indicator kinerja Gizi. gizi.depkes.go.id/wpcontent/uploads/FINAL_hasil_PSG_20 15.pdf

Hodgson, Z., Saxell, L., \& Christians. (2017). An evaluation of interprofessional group antenatal care: a prospective comparative study. BMC Pregnancy and childbirth (2017) 17:297

Mann, J. \& Truswell, S. (2012). Essentials of Human Nutrition. New York: Oxford University Press

Pranata, S., Pratiwi, N., \& Rahanto, S. (2011). Pemberdayaan Masyarakat di bidang Kesehatan, Gambaran peran Kader Posyandu dalam upaya penurunan angka kematian ibu dan bayi di Kota Manado dan palangkaraya. Buletin Penelitian system Kesehatan. Vol. 14 No 2 April 2011: 174-182
Ramdani, M \& Hadi, E. (2010). Dukungan Suami dalam Pemberian ASI Eksklusif di Wilayah Kerja Puskesmas Air Tawar Kota Padang. Jurnal Kesehatan Masyarakat Nasional No 6, Juni 2010, Vol.4.

Susilo, J., Kurdanti, W., \& SiSwati, T., (2012). Hubungan Program Kelompok pendukung ibu terhadap pengetahuan dan praktik pemberian ASI Eksklusif. Gizi Indon 2012, 35 (1):30-40

Widayati, R., \& Wahyuningsih, I. (2015). Pelatihan dan Implementasi Konselor Peer-Support Berbasis Masyarakat pada Kelompok Pendukung ASI Eksklusif. Jurnal STIKES A 'isyiyah Surakarta No 1 Nopember 2015,vol4.

Yuliana, Wahida. (2016). Efektifitas Pijat Punggung Menggunakan Minyak Essensial Lavender Terhadap Produksi ASI Ibu Pasca Salin. Jurnal Kebidanan dan Keperawatan Stikes 'Aisyiyah Yogyakarta. No.1, Juni 2016, Vol 12. 